\title{
Research on the Visa Service Quality of Chinese Outbound Tourists Based on the SERVQUAL Model
}

\author{
Kaibo Zhou \\ Shanghai Normal University Tianhua College \\ Shanghai 201815
}

\begin{abstract}
China has become the world's largest source of outbound tourists. With the surge of the number of outbound tourists, the problem of visa service for outbound tourists becomes more and more prominent. Effective evaluation and improvement of quality are the key factors to optimize the tourist visa service. Therefore, this paper chooses the service quality of outbound tourist visa as the research object, uses SERVQUAL model to conduct questionnaire survey, data analysis and effective evaluation on visa service quality, and proposes improvement measures for existing problems in visa service. This study hopes to provide a reference for the improvement of visa service quality of Chinese outbound tourists.
\end{abstract}

Keywords-outbound tourists, visa service, quality evaluation, SERVQUAL model

\section{INTRODUCTION}

With the development of economy and social progress, the outbound tourism of Chinese tourists is developing rapidly, making more and more contributions to the development of international tourism. At the same time, the quality of tourist visa service is becoming more and more prominent. "Visa agencies cannot keep their promise, nor give priority to the interests of customers, making customers lose their sense of trust and honesty in visa services and creating a vicious circle. This is a difficult problem faced by most visa agencies at present."[1]. Therefore, this paper chooses SERVQUAL evaluation model as a research tool to design the evaluation scale of visa service. Through a questionnaire survey and data analysis, it points out the problems and causes of visa service and puts forward countermeasures to solve the problems, aiming to provide a reference for tourist visa service enterprises.

\section{A. Tourist visa}

"Tourist visa is one of visas, which is a fast way to apply for a visa to facilitate tourists to travel abroad. It has the advantages of convenient processing, strong flexibility and relatively high visa issuing rate for the whole group. Accordingly, due to its particularity, it has the defects of a short period of validity and duration of stay with many restrictions. It can only be used for tourism-related activities. " [2]

The tourist visa discussed in this study is mainly for visa required for personal transit, excluding other types of visa.

\section{B. Tourist visa service}

At present, travel agencies mainly help people apply for tourist visa. This includes group and individual tourist visas. "The qualification record of travel agencies in each consulate can provide a certain guarantee for the visa issuing rate. In particular, large travel agencies with more outbound business have higher credibility and greater advantages in the visa issuing rate." [3]

Travel agencies engaged in outbound tourism have special visa teams. On the one hand, the visa team will communicate and negotiate with the consulates of various countries. On the other hand, the visa team will communicate with the guests. Through two-way communication, we can provide more professional service to guests and solve related problems in time.

\section{Customer perceived service quality}

"Customer perceived service quality is also known as service quality. In 1982, Gronroos (1982) first proposed the concept of customer perceived service quality. It is defined as a comparison between customers' expectations on service and perceived performance. If perceived performance is greater than the service expectation, then customers perceive the service quality to be good, and vice versa." [4]

\section{SERVQUAL Model}

SERVQUAL (Service Quality) first appeared in 1988 in the article SERVQUAL: a multivariable measure of customer perceived service quality jointly written by $\mathrm{PZB}$, that is, Parasuraman, Zeithaml, and Berry. [5]

SERVQUAL model evaluates the service quality, which is based on tourists' expected service and perceived service after receiving the service. $\mathrm{PZB}$ proposed the five-dimension view of service quality, based on which they designed a questionnaire with 22 items. The five dimensions are tangibility, reliability, responsiveness, assurance and empathy. According to PZB calculation, the correlation coefficient between these five dimensions and customer perceived service quality is as high as 0.92. [6] 


\section{QUESTIONNAIRE}

\section{A. Design and distribution of the questionnaire}

The author designed a questionnaire on visa service quality of Chinese outbound tourists with reference to 5 dimensions and 22 evaluation items of the SERVQUAL model, as shown in TABLE I.

TABLE I. SERVQUAL QUESTIONNAIRE ON VISA SERVICE QUALITY OF CHINESE OUTBOUND TOURISTS

\begin{tabular}{|c|c|c|c|}
\hline \multirow{2}{*}{ Dimension } & \multirow{2}{*}{ Evaluation items } & \multicolumn{2}{|c|}{ Tourists' score } \\
\hline & & Expected value (5 points) & Perceived value(5 points) \\
\hline \multirow{4}{*}{$\begin{array}{c}\text { Tangibility } \\
\text { A }\end{array}$} & A1 Modern facility & & \\
\hline & A2 Improved network system & & \\
\hline & A3 Neatly-dressed employee & & \\
\hline & A4 Facilities are matched with service & & \\
\hline \multirow{5}{*}{$\begin{array}{l}\text { Reliability } \\
\text { B }\end{array}$} & B1 Fulfill commitment & & \\
\hline & B2 Serve and help customers in time & & \\
\hline & B3 Trustworthy and be reliable & & \\
\hline & B4 Provide service timely & & \\
\hline & B5 Deliver promised services on time & & \\
\hline \multirow{4}{*}{$\begin{array}{c}\text { Responsiveness } \\
\text { C }\end{array}$} & C1 Inform the exact service hours & & \\
\hline & C2 Timely service to meet guest expectations & & \\
\hline & C3 Be willing to help guests & & \\
\hline & C4 Don't neglect guests because of busyness & & \\
\hline \multirow{4}{*}{$\begin{array}{c}\text { Assurance } \\
\text { D }\end{array}$} & D1 trustworthy employees & & \\
\hline & D2 Provide assurance service & & \\
\hline & D3 Employees are always polite & & \\
\hline & D4 Employees work together & & \\
\hline \multirow{5}{*}{$\begin{array}{c}\text { Empathy } \\
\text { E }\end{array}$} & E1 Provide personalized service & & \\
\hline & E2 Employees care about customers & & \\
\hline & E3 Employees know customers' needs & & \\
\hline & E4 Prioritize customers' interests & & \\
\hline & E5 Service hours are available to all customers & & \\
\hline
\end{tabular}
5 points is for very important, 4 points for relatively important, 3 points for important, 2 points for general, and 1 point for irrelevant.

When tourists score their perception on evaluation items, 5 points is for very satisfied, 4 points for relatively satisfaction, 3 points for their satisfaction, 2 points for the general, and 1 point for their dissatisfaction
The author takes tourists from travel agencies in 10 cities, including Beijing, Shanghai and Guangzhou, who applied for outbound tourist visas, as research objects. 208 questionnaires are issued on the spot to conduct the survey. 8 invalid questionnaires are eliminated and 200 valid questionnaires are collected.

\section{$B$. The result of the questionnaire}

The author uses SPSS21.0 to conduct statistics on the data and the results are shown in TABLE II

TABLE II. THE RESULT OF THE SURVEY OF SERVICE QUALITY OF OUTBOUND TOURIST VISA FOR CHINESE TOURISTS

\begin{tabular}{|c|c|c|c|c|c|}
\hline Index & Expectation (E) & Perception(P) & Service quality(SQ) & Standard deviation（SD） & Standard error（SE) \\
\hline A1 & 4.55 & 4.45 & -0.10 & 0.90588 & 0.06040 \\
\hline A2 & 4.27 & 4.02 & -0.25 & 0.93219 & 0.06132 \\
\hline A3 & 4.35 & 4.31 & $\begin{array}{l}-0.04 \\
\end{array}$ & 0.96527 & 0.06244 \\
\hline A4 & 4.60 & 3.88 & $\begin{array}{l}-0.72 \\
\end{array}$ & 0.94469 & 0.06321 \\
\hline B1 & 4.87 & 4.07 & -0.80 & 0.86863 & 0.05765 \\
\hline B2 & 4.85 & 3.97 & $\begin{array}{l}-0.88 \\
\end{array}$ & 0.93425 & 0.06543 \\
\hline B3 & 4.93 & 4.23 & -0.70 & 0.94435 & 0.06312 \\
\hline B4 & 4.80 & 3.85 & -0.95 & 0.89087 & 0.05456 \\
\hline B5 & 4.55 & 4.25 & -0.30 & 0.92366 & 0.05345 \\
\hline C1 & 4.75 & 4.13 & $\begin{array}{l}-0.62 \\
\end{array}$ & 0.85098 & 0.05885 \\
\hline C2 & 4.63 & 3.89 & -0.74 & 0.94532 & 0.06289 \\
\hline C3 & 4.72 & 3.95 & -0.77 & 0.98760 & 0.06796 \\
\hline C4 & 4.55 & 3.68 & $\begin{array}{l}-0.87 \\
\end{array}$ & 0.91065 & 0.06982 \\
\hline D1 & 4.71 & 3.84 & -0.87 & 0.96506 & 0.06024 \\
\hline D2 & 4.80 & 3.90 & -0.90 & 0.89018 & 0.05786 \\
\hline D3 & 4.70 & 3.75 & -0.95 & 0.87009 & 0.05954 \\
\hline D4 & 4.55 & 4.12 & -0.43 & 0.87706 & 0.05954 \\
\hline E1 & 4.56 & 4.46 & $\begin{array}{l}-0.10 \\
\end{array}$ & 0.89832 & 0.05974 \\
\hline
\end{tabular}


Cont. to TABLE II

\begin{tabular}{c|l|l|l|l|l}
\hline E2 & 4.41 & 4.11 & -0.30 & 0.93873 \\
\hline E3 & 4.54 & 4.21 & -0.33 & 0.06110 \\
\hline E4 & 4.65 & 3.98 & -0.67 & 0.06971 \\
\hline E5 & 4.55 & 4.06 & -0.49 & 0.86006 \\
\hline
\end{tabular}

According to the data in TABLE II, the evaluation results of service quality in 22 evaluation items are all negative, indicating that the current customers' perception on visa service quality is generally lower than their expectation, and the service quality needs to be improved as a whole.

The author calculates the mean value in accordance with 5 dimensions and obtains the evaluation of service quality of each dimension, as shown in TABLE III. Customers' expectation on visa service quality is ranked from high to low as reliability, assurance, responsiveness, empathy and tangibility. Their perceived value of visa service quality ranks from high to low as tangibility, empathy, reliability, responsiveness and assurance. The perceived value is subtracted from the expected value to get the ranking of visa service quality. At present, the most serious problem of the quality of visa service is assurance service, with a gap of -0.79 , followed by the responsive -0.75 and the reliable -0.73 . The service quality of empathic -0.38 and tangible -0.27 do not satisfy customers, either

TABLE III. EVALUATION OF VISA SERVICE QUALITY OF CHINESE OUTBOUND TOURISTS FROM ALL DIMENSIONS

\begin{tabular}{c|c|c|c}
\hline Dimension & Expected value & Perceived value & Service quality \\
\hline Tangibility & 4.44 & 4.17 & -0.27 \\
\hline Reliability & 4.80 & 4.07 & -0.73 \\
\hline Responsiveness & 4.66 & 3.91 & -0.75 \\
\hline Assurance & 4.69 & 3.90 & -0.79 \\
\hline Empathy & 4.54 & 4.16 & -0.38
\end{tabular}

Service quality plays a very important role in tourist visa for outbound tourists. Based on the service quality with the SERVQUAL evaluation model, the author further analyzes the problems and reasons of visa service.

\section{PROBLEMS AND REASONS FOR VISA SERVICE QUALITY OF CHINESE OUTBOUND TOURISTS}

\section{A. Tangible service: lack of supporting facilities}

China's visa business has a slow start. For most of the old travel agencies with outbound visa qualifications, it is difficult to update the old hardware equipment and keep pace with the internationalization of visa business. Because the visa photos do not meet the requirements of the consulate, outbound tourists often have to re-take the photos many times. And visa departments of travel agencies have not the standard photo facilities, thus tourists often return to the photo studio many times. Many consulates of countries and regions have different requirements on equipment. Take Singapore visa and Exit-Entry Permit for Travelling to and from Taiwan for example, both visa pages are paper, and it is impossible to complete on-site color printing without color printer. At present, many visa departments of travel agencies are not equipped with their own document photo machines, multi-functional color printing machines and scanners and other equipment, thus reducing the quality of service.

\section{B. Reliable service: do not focus on fulfilling the commitment}

Tourists rated the reliability of visa service as -0.73 , indicating a low degree of satisfaction. Many customers who suffer from visa refusal or delay will face double economic losses of air tickets and hotels, and visa refusal even leaves bad records in tourists' passports. When tourists are ready to defend their rights or learn more about the facts, the visa department always presents a series of exemption clauses or gives various reasons to shirk the responsibility. It is a dilemma for those customers. When a visitor is refused visa by any countries, that "visa refusal is decided by the consulate" becomes a standard

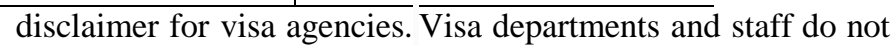
attach importance to the commitment and are unwilling to fulfill the commitment, thus leading to the continuous decline of tourists' trust in visa services.

\section{Responsive service: neglecting customers' needs}

The most direct experience for customers in expectations on service quality is from the service of visa personnel. At present, visa service personnel holds a negative attitude towards work and lacks of enthusiasm. It is very common for them to ignore customers due to busy business and complicated visa procedures. And long-term poor working habits and lax attitude make them lack of sincere communication and effective exchange with customers, thus they cannot fully understand the customer's demand and be unable to make timely feedback to customer needs. Tourists thus frequently fail to get the visa services or wait for long time due to the lack of visa-related document; hence they cannot book flight ticket and hotel at low price in advance.

\section{Assurance of service: weak awareness of service}

The evaluation of service quality of assurance is lowest, reaching-0.79. When applying for visa, the staff has a good command of the tourists' personal information, asset status, social relations and other information. Sometimes due to poor management, the tourists receive a large number of marketing information such as loans and insurance. Due to the lack of training, some employees in the visa department are not good at professional skills, communication and teamwork. In the face of customers' inquiries and requirements, their performance is not good enough. In the process of providing visa services, they cannot work together. Thus, the service time for applying for visa and final result of visa cannot be guaranteed and customers' evaluation is relatively low.

\section{E. Empathy of service: lack of people-to-people care}

Due to the large volume of business, visa departments in most travel agencies pay more attention to the overall 
economic benefits rather than personalized care for tourists. Some visa personnel think that the refusal of visa is related to the interests of customers, which does not affect their performance assessment, nor the overall benefit of the visa department. Therefore, in the visa service, visa service personnel often only pay attention to the results of checking and standard procedures, but neglect the meticulous and personalized service. Even if they have to bear financial compensation due to service defects, they cannot be empathetic to customers.

\section{MEASURES TO IMPROVE THE QUALITY OF VISA SERVICES FOR CHINESE OUTBOUND TOURISTS}

\section{A. Speeding up the update of the facilities in the visa department}

Outbound tourist visa departments should be equipped with self-service ID photo machines, multi-functional color printing machines and scanners and other equipment. At the same time, the visa department should recruit technical personnel and create a convenient and efficient multi-functional network system to share and spread information. Through equipment and talents, tourists can enjoy high-quality, safe and convenient visa services.

\section{B. Enhancing the sense of responsibility of the visa department}

Visa agencies should strengthen their own sense of responsibility and establish a responsibility system in the process of accepting visa applications. When accepting the visa application from the customer, the customer whose materials meet the requirements should be given a positive reply. For customers with unqualified materials, they should not simply be refused, but given guidance. For customers who need to improve the materials, they should be contacted and provided assistance. For customers who are interviewed at the consulate, they should be provided targeted training to familiarize themselves with the process and requirements. After the application materials are sent to the embassy, the visa agencies should pay attention to the progress in a timely manner and properly solve the problem. They can adopt the method of mid-course cancellation to avoid the rejection of clients.

\section{Paying more attention to the visa requirements of tourists}

The visa department should pay attention to communication with customers, timely understand their needs and make quick judgment and feedback. At the same time, the attitude of the staff should be improved to make them more friendly, polite and enthusiastic, help customers solve problems quickly and effectively, improve the efficiency of work, let customers enjoy satisfactory service, and enhance customer loyalty.

\section{Improving the business level of visa service personnel}

Visa agencies should increase training on staff, improve performance appraisal management system, and enhance their service level from the following three aspects: First, they should communicate with customers patiently and efficiently to strengthen the relationship between customers and the company; Second, cooperation among employees should be strengthened in order to improve service efficiency, create a harmonious service environment and improve the company image; Third, they should have excellent business level to provide tourists with correct guidance, thus improving customer satisfaction.

\section{E. Enhancing people-to-people care to customers}

Visa agencies should give priority to the interests of customers and establish a customer database. On the one hand, they should strengthen the confidentiality of customer information, and on the other hand, they should simplify the process of repeated submission of materials for multiple visa applications. Customers can grade the service of visa agency in order to evaluate their staff in a multi-dimensional way, so as to improve the perceived service quality, increase the people-to-people care for customers and make them feel personalized service.

\section{CONCLUSION}

In this paper, the visa service quality for Chinese outbound tourists is taken as the research object. Combined with the SERVQUAL model, the visa expected and perceived values of outbound tourists are studied through a questionnaire, data analysis and interview. This paper analyzes the problems and causes of the visa service quality of Chinese outbound tourists. In addition, improvement measures are proposed from five aspects: speeding up the updating of the facilities in visa department, strengthening the sense of responsibility of the visa department, paying more attention to visa requirements of tourists, improving the business level of visa service personnel, and enhancing people-to-people care to customers, hoping to provide help for the tourist visa agencies to improve their service quality. There are many perspectives on the study of tourist visa service quality. Although some attempts have been made in research in this paper, the sample size is not large enough and the analysis is not deep enough. Only some superficial opinions can be put forward for reference.

\section{REFERENCES}

[1] Fang Zengfu. Management on Travel Agency[M]. Beijing: Science Press, 2010.34-38

[2] Lu Xiaolin. Study on the Problem of Tourist Visa Refusal and Countermeasures [J]Tourism Management Research, 2015(9):14-15

[3] Zhang Shehua. On Supply-side Reform and the Improvement of the System of China's Tourist Visa[J]Economic Development Research, 2017(8):158-159.

[4] Han Jinlun, Dong Jun. Evaluation and Management of Customers Perceived Service Quality[M]. Tianjian: Nankai University Press, 2006:45-60

[5] Chen Ruixia, Wang Wenjun, On the Application of SERVQUAL in Evaluation of Service in Hotel Industry[J]. Journal of Beijing International Studies University, 2005(3):59-62.

[6] Parasuraman, Zeithmal and Berry. SERVQUAL: A mulitiitem scale for measuring customer perceptions of service quality[J].Journal of Retailing,1988,64:12-40. 